\title{
Epidemiological study of snakebite cases in Brazilian Western Amazonia
}

\author{
Katia Regina Pena Schesquini Roriz ${ }^{[1]}$, Kayena Delaix Zaqueo ${ }^{[2],[3], ~ S u l a m i t a ~ S i l v a ~ S e t u b a l ~}{ }^{[2],}$ \\ Tony Hiroshi Katsuragawa ${ }^{[4]}$, Renato Roriz da Silva ${ }^{[1]}$, Carla Freire Celedônio Fernandes ${ }^{[2] .[4]}$, \\ Luiz Augusto Paiva Cardoso ${ }^{[5]}$, Moreno Magalhães de Souza Rodrigues ${ }^{[2]}$, \\ Andreimar Martins Soares ${ }^{[2]}$, Rodrigo Guerino Stábeli ${ }^{[1],[2]}$ \\ and Juliana Pavan Zuliani ${ }^{[1],[2]}$
}

\author{
[1]. Departamento de Medicina, Universidade Federal de Rondônia, Porto Velho, RO, Brasil. \\ [2]. Fundação Oswaldo Cruz-Rondônia, Porto Velho, RO, Brasil. \\ [3]. Centro de Referência de Jaciara, Instituto Federal de Educação, Ciência e Tecnologia de Mato Grosso, Campus São Vicente, Jaciara, MT, Brasil. \\ [4]. Centro de Pesquisa em Medicina Tropical, Porto Velho, RO, Brasil. \\ [5]. Centro de Medicina Tropical de Rondônia, Porto Velho, RO, Brasil.
}

\begin{abstract}
Introduction: Brazil has the largest number of snakebite cases in South America, of which the large majority is concentrated in the Midwest and North. Methods: In this descriptive observational study, we assessed the epidemiological and clinical snakebite cases referred to the Centro de Medicina Tropical de Rondonia from September 2008 to September 2010. Results: We followed up 92 cases from admission until discharge, namely 81 (88\%) men and 11 (12\%) women, with a mean age of 37 years, and mainly from rural areas $(91.3 \%)$. The snakebites occurred while performing work activities (63\%) during the Amazon rainy season (78.3\%). The vast majority of individuals presented from the Porto Velho microregion (84.7\%). Approximately $95.6 \%$ of the snakebites were caused by snakes of the genus Bothrops, followed by two lachetics and two elapidics cases. Surgery was performed in 10 cases ( 9 fasciotomies in the lower limb and 1 amputation). No deaths were reported in this study, but 4 cases (4.3\%) developed sequelae in the lower limb. Conclusions: This study can contribute to a better understanding of envenomation in the state of Rondônia and thus can be useful for identifying real conditions that can increase the incidence of snakebites in this region. Moreover, the study results can serve as a basis for improving educational campaigns designed to prevent these types of snakebites, as well as for preserving snakes.
\end{abstract}

Keywords: Snakebite. Clinical. Epidemiology. Viperidae. Neglected disease.

\section{INTRODUCTION}

Envenomation caused by venomous snakes is a serious public health problem and can sometimes be complex owing to its global scope and the involvement of different snake species that live in specific environments, which deserve the attention of governmental authorities. These environmental and occupational envenomations particularly affect the rural communities of Latin America, especially in Brazil ${ }^{1-3}$.

Since snakebites affect, in most cases, poor people living in the rural areas of tropical countries ${ }^{4}$, representing a condition of poverty, the World Health Organization (WHO) incorporated snakebite envenoming in its list of neglected conditions ${ }^{5}$.

Corresponding author: Dra. Juliana Pavan Zuliani

e-mail: juliana.zuliani@fiocruz.br; juliana.zuliani@unir.br

Received 27 December 2017

Accepted 18 May 2018
Recently, snakebite envenomation was classified as a neglected tropical disease ${ }^{1,2}$. Snakebites have great medical importance because they occur with high frequency and severity and are associated with morbidity and mortality ${ }^{6}$. It is noteworthy that snakebites have been recognized as notifiable disease since 1986, thus allowing a better understanding of its epidemiology.

Brazil has the highest number of snakebite cases in South America, with about 26,000-29,000 cases per year, followed by Venezuela $(7,000)$, Colombia $(3,000)$, Ecuador $(1,400-1,600)$, Peru $(1,400-1,500)$, and Bolivia $(1,000)^{7}$. However, latest data showed a reduction in the impacts caused by envenomations involving venomous snakes. This reduction is mainly related to the improvement in the attendance of patients ${ }^{8}$.

Among the Brazilian regions, the Midwest and North have the highest number of bitten cases per 100,000 people $^{9}$. It is noteworthy that the Northern region has the highest proportion of snakebite cases in relation to the population (520 snakebites/ million inhabitants), which may have aggravated the difficulties 
in both mobility and communication ${ }^{10,11}$. According to the data from the Brazil's Information System for Notifiable Diseases [Sistema de Informação de Agravos de Notificação (SINAN)], Secretary of Health Surveillance, and Ministry of Health (MH) from 2000 to 2007, Rondônia is one of the states in the North that has the highest number of snakebite cases, with a total of 4,455 cases during this period.

The majority of snakebite cases reported in Latin America is caused by different species of snakes of the genus Bothrops (of the Viperidae family) ${ }^{12,13}$. In Brazil, the majority of snakebite cases are commonly caused by five groups of snakes: Group I (caissaca, urutu, and jararacussu, among others, of the genus Bothrops), Group II (cascavel, of the genus Crotalus), Group III (pico de jaca, of the genus Lachesis), Group IV (coral-verdadeira, of the genus Micrurus), and Group V (cobras-cipós, some opisthoglyphous snakes of the genus Philodryas, among others) ${ }^{13,14}$. In the Northern Brazilian region (Amazon), especially in Rondônia, the species Bothrops atrox, whose venom triggers local and systemic effects in its victims, is responsible for the majority of snakebites ${ }^{6,12,15}$. About $80 \%-90 \%$ of snakebites are treated at the Centro de Medicina Tropical de Rondônia (CEMETRON) in Porto Velho, Rondônia.

To our knowledge, this is the first study to evaluate the epidemiological and clinical aspects of snakebite cases reported from 2008 to 2010 in CEMETRON, Porto Velho to establish a better prognosis and more detailed analysis of individual envenoming because snakebites still constitute a serious public health problem in Brazil.

\section{METHODS}

\section{Study area}

With about 1,562,409 inhabitants, the State of Rondônia, which is part of Western Amazon, covers an area of $237,590.547 \mathrm{~km}^{2}$. The capital of Rondônia, Porto Velho, is located on the right bank of the Madeira River, the largest tributary of the Amazon River. Porto Velho is located in Northwest Brazil and covers an area of $34,082.370 \mathrm{~km}^{2}$. Most municipalities of Rondônia are small and have low population densities. It has a humid tropical climate with a slightly pronounced dry season. The rainfall varies from $1,900 \mathrm{~mm}$ in the South to $2,500 \mathrm{~mm}$ in the North. The temperature remains high throughout the course of the year, with annual averages above $26^{\circ} \mathrm{C}$. About $70 \%$ of the surface of Rondônia is covered by the Amazon rainforest. The remaining 30\% are part of the Cerrado savannah and a flat plateau. The economy is based on farming and agriculture (coffee, cocoa, rice, cassava, and maize) and the extraction of timber, minerals, and rubber.

\section{Data collection}

This is a descriptive observational study of the clinical aspects of patients who were victims of snakebite based on cases reported from September 2008 to September 2010. The patients admitted to Centro de Medicina Tropical de Rondônia (CEMETRON) in Porto Velho were followed up until patient discharge.

\section{Subjects}

Patients presented to CEMETRON with complaints of snakebites.

Ethical aspects: approved by the Brazilian IRB (Institutional Review Board, Ethics Committee of CEPEM - Plataforma Brasil) of the Centro de Pesquisa em Medicina Tropical (CEPEM-RO) approval number (080/2008). All adult subjects provided informed consent. All the given informed consent was written.

Criteria for inclusion and exclusion: patients aged 18-59 years regardless of sex were included in the study. In contrast, vulnerable groups (indigenous, the elderly aged $>60$ years, pregnant women, and children) and individuals with pre-existing renal and liver diseases were excluded. This group was not included in this study as they are considered a special group by the National Committee of Ethics in Research, Brazil.

Protocol: with regard to the admission of a snakebite victim in this study, the following variables were checked: age, education, occupation, site of the bite, whether the animal was identified, season of the year, area of occurrence, city, activity performed at the time of the snakebite, procedure performed at the time of the bite, use of alternative medicines, local and systemic symptoms, treatment, hospitalization time, and evolution.

Criteria for snakebite classification: In Brazil, the evaluation of snakebite severity is standardized according to the criteria established by the MH based on the diagnostic manual and treatment of envenomations ${ }^{6}$.

Identification of captured snakes: The snakes were identified by knowledgeable herpetologists based on the characteristics of the families and genera of the snakes.

Blood collection: blood collection was performed by a team of professionals from CEMETRON (medical, nursing, and/or biochemical). A total of $5 \mathrm{~mL}$ was collected prior to and 48 hours after serum therapy and was used to determine the biochemical parameters of clotting time (CT), blood cell count, urea, creatinine, alanine aminotransferase (ALT), aspartate aminotransferase (AST), and creatine kinase (CK).

\section{Statistical analysis}

The analyses were performed using EPI-INFO 3.5.1. When appropriate, the mean (standard deviation) and median (interquartile range) were used to describe variables. The null hypothesis stating that quantitative variables (laboratory tests before and after serum therapy) are normally distributed was tested using the Shapiro-Wilk test. Results showed that our data could not be described by a normal distribution; thus, quantitative variables were analyzed using the Mann-Whitney test. All analyses were performed at a significance level of 5\%.

A spreadsheet was constructed containing the Global Positioning System data of snakebite occurrence. The severity data were imported into the public access spatial analysis program Terra View 4.1.0 $0^{10}$ to perform Kernel density estimation analysis. 


\section{RESULTS AND DISCUSSION}

Characterized as a Neglected Tropical disease, snakebites are also important occupational debilities ${ }^{10}$. Brazil has shown an increasing trend in the number of snakebite cases each year, and the North and Midwest are the Brazilian regions with the highest numbers of snakebite cases ${ }^{16}$. Population growth in cities associated with the increased Brazilian agricultural frontier, mainly in the North, are factors that have contributed to the growing number of snakebite cases. The state of Rondônia has been categorized as a medium-sized state $(0.736)$ based on the Human Development Index, which was also reported in previous studies ${ }^{4,16}$.

In this first study in Rondônia, we followed up 92 snakebite cases (Figure 1-I and Figure 1-II) from 2008 to 2010. Most of these snakebites cases occurred in Porto Velho, mainly in the rural areas, which corresponds to a total of $84(91.3 \%)$ cases (Table 1). The victim was performing his/her work activities at the time of the snakebite (63\%) (Table 2). Figure 1-IIIA shows the occurrence of snakebites. The Kernel analysis showed that a higher number of severe snakebite cases were reported in the Madeira River (Figure 1-IIIB and Figure 1-IIIC, orange line), in the municipality of Porto Velho. Some of these snakebites occurred among those living near the Santo Antonio and
Jirau hydroelectric power plants. Kernel density distributions showed the severity of snakebite cases in Figure 1-IIID (mild), Figure 1-IIIE (moderate), and Figure 1-IIIF (severe).

Data from SINAN updated in September 2007 showed that the number of envenomations is increasing and Rondônia ranks fourth among the states in Brazil with the highest reported snakebite cases. Two important factors may have influenced this increase: I) the growing number of forest fires in the region ${ }^{17}$ and II) the construction of two hydroelectric power plants (San Antonio and Jirau) in the capital Porto Velho, which began between 2008 and 2009, and started operating in 2011 and 2013, respectively. It is crucial to highlight that the population growth, which is directly or indirectly associated with the hydroelectric power plants, may have surpassed 100,000 inhabitants ${ }^{17}$. The increase in the population near the hydroelectric power plants left them exposed to wildlife species, contributing to the displacement of snakes near places inhabited by humans and creating conditions that can increase the occurrence of snakebites.

A higher incidence of envenomations occurred in Amazon during the rainy season, which is characterized by high temperatures and high rainfall, causing an overflow in rivers banks, streams, and dams, forcing the snakes to move to land

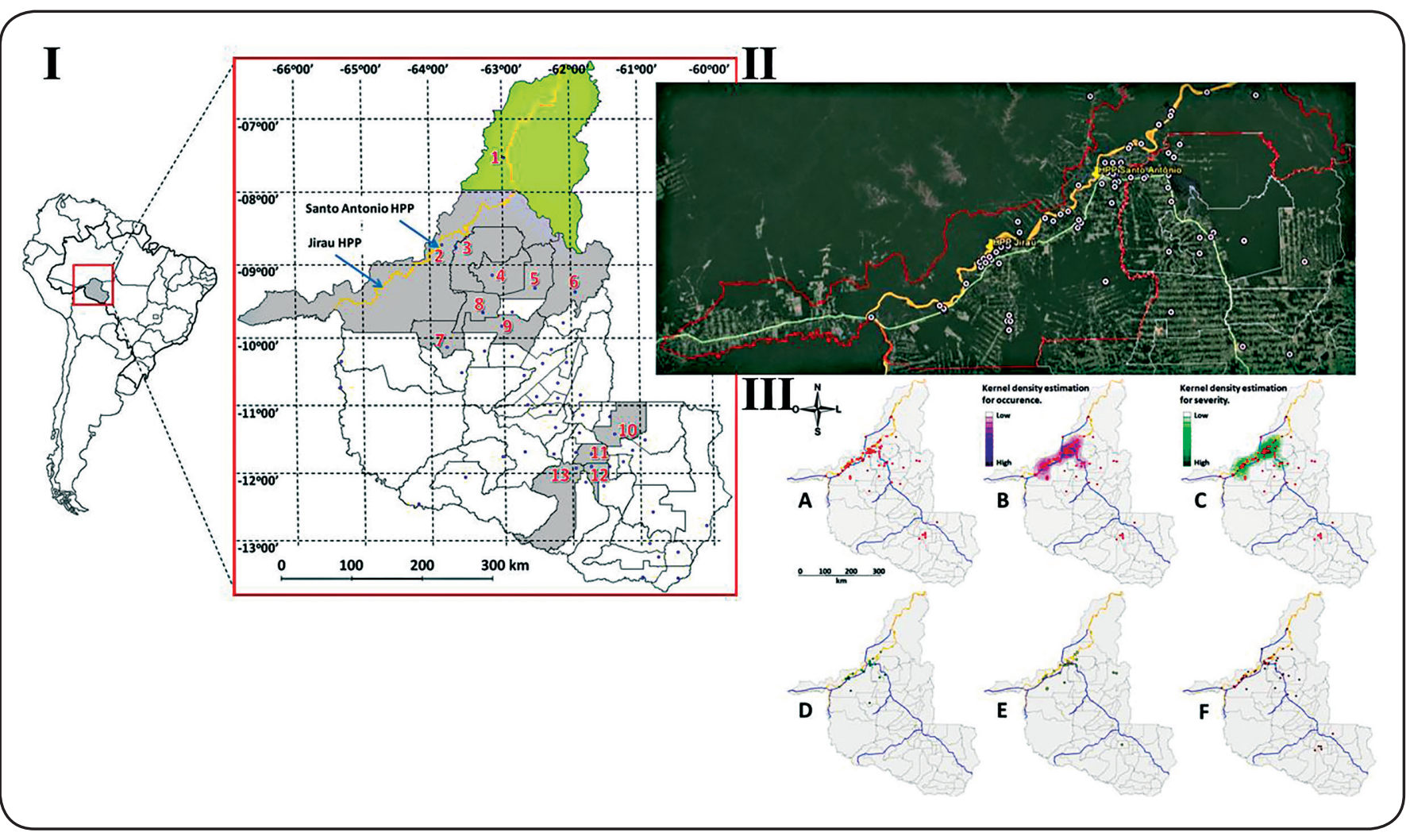

FIGURE 1 - I: Location of the study area, State of Rondônia, Brazil. The large red square indicates the State of Rondônia, and the municipality of Humaitá is in green (State of Amazonas). The orange line indicates the Madeira River. Blue spots indicate the city locations. Red numbers indicate the cities with snakebite cases recorded, which were highlighted in gray. The blue arrows indicate the hydroelectric power plants of Jirau and Santo Antonio. II: Location of the municipalities along the Madeira River, municipality of Porto Velho, State of Rondônia. White circle: Location of snakebite occurrence; red line: Porto Velho municipality border; orange color: Madeira River; light green line: main roadway BR 364 . HPP Santo Antonio $\left(-08^{\circ} 48^{\prime 2} 25,23^{\prime \prime}\right.$ S; $-63^{\circ} 56^{\prime 2} 24,38^{\prime \prime}$ W) and HPP Jirau (-09 $16^{\prime} 34,78^{\prime \prime}$ S; $-64^{\circ} 30^{\prime} 15,01^{\prime \prime}$ W). III: Location of snakebite occurrence (A), Kernel density estimation for occurrence (B), and severity (C). High snakebite occurrences around Porto Velho city and the Jirau hydroelectric power plant were observed. The severity occurrence distribution by classification is shown in $\mathbf{D}$ (mild), $\mathbf{E}$ (moderate), and $\mathbf{F}$ (severe). 
TABLE 1: Descriptive aspects of municipalities and number of snakebite cases recorded by severity.

\begin{tabular}{|c|c|c|c|c|c|c|c|c|}
\hline ID* & Municipality & State & $\begin{array}{l}\text { Area } \\
\mathbf{k m}^{2}\end{array}$ & POP & SBCR & \multicolumn{3}{|c|}{ Severity $(\%)^{\star *}$} \\
\hline 2 & Porto Velho & RO & 34,10 & 428,52 & 60 & $18(30.0)$ & $17(28.3)$ & $25(41.7)$ \\
\hline 3 & Candeias do Jamari & RO & 6,85 & 19,78 & 12 & $2(16.7)$ & $4(33.3)$ & $6(50.0)$ \\
\hline 5 & Cujubim & RO & 3,86 & 15,85 & 1 & - & - & $1(100.0)$ \\
\hline 6 & Machadinho D'Oeste & RO & 8,51 & 31,13 & 2 & - & $2(100.0)$ & - \\
\hline 7 & Buritis & RO & 3,26 & 32,38 & 1 & $1(100.0)$ & - & - \\
\hline 8 & Alto Paraíso & RO & 2,65 & 17,13 & 1 & - & - & $1(100.0)$ \\
\hline 12 & Santa Luzia D'Oeste & RO & 1,20 & 8,89 & 1 & - & - & $1(100.0)$ \\
\hline \multirow[t]{2}{*}{13} & Alta Floresta D'Oeste & RO & 7,07 & 24,39 & 1 & - & - & $1(100.0)$ \\
\hline & Total & & & & & $22(23.9)$ & $24(26.1)$ & $46(50.0)$ \\
\hline
\end{tabular}

ID: Identification; POP: population; SBCR: snakebite cases recorded; AM: Amazonas; RO: Rondônia. **1 = mild; 2 = moderate; $3=$ severe.

and increasing the risk of injury to people. This report can be confirmed using the data from the Instituto Brasileiro de Geografia e Estatística (IBGE) ${ }^{1}$. Snakebites frequently occur in the lower limbs primarily due to the lack of use of protective equipment during fieldwork, as reported in previous studies $19,21-23$.

About 72 (78.3\%) cases occurred between the months of November and April, which corresponds to the Amazon rainy season. Regarding the time of day when the snakebite occurred, the diurnal period was predominant with 70 cases, representing $76 \%$ of the envenomations. Table 2 shows the distribution of cases according to sex: $81(88 \%)$ were men and $11(12 \%)$ were women. The median age was 37.35 years ( \pm 12 years). Approximately $88 \%$ of the patients were literate and $63 \%$ of them were rural workers. The number of snakebite cases increased during the brightest period of the day, although most venomous snakes have nocturnal habits, which corroborates the results of previous studies ${ }^{11,18-20}$.

This study showed that the incidence of snakebites was higher among rural workers aged 20-49 years, affecting especially the lower limbs (Table 2) ${ }^{1,2,9,25}$, and 44 (47.8\%) patients used alternative medicine (Table 3 ).

With regard to the type of snakebite, bothropic envenomations were predominant with $88(95.6 \%)$ cases, followed by $2(2.2 \%)$ cases of Lachesis and 2 (2.2\%) cases of Micrurus. It is important to mention that only $19(20.6 \%)$ snakes were captured, and they were identified by a herpetologist (Dr. Kayena D. Zaqueo from FIOCRUZ-RO) as follows: 18 were Bothrops atrox snakes and one was a Micrurus lemniscatus snake. In cases where the snake was not brought to the hospital, the genus was identified based on the patients' sign and symptoms. The following were the mortality rates of snakebites in Brazil: snakebites by Bothrops, $0.3 \%$; Crotalus, $1.9 \%$; Lachesis, $0.9 \%$; and Micrurus, $0.5 \%{ }^{21,20}$. No deaths were reported during the study, whose mortality rate is the lowest among all the snakebites from different species in Brazil.

As shown in Table 3, the time elapsed between the snakebite and arrival at the hospital was longer than 6 hours in $64(72.7 \%)$ patients and less than 6 hours in $24(27.3 \%)$ patients. Based on the severity of snakebites, $22(23.9 \%)$ cases were classified as mild, $24(26.1 \%)$ as moderate, and $46(50 \%)$ as severe envenomations (Table 1). Delays between the occurrence of snakebite and receiving assistance (hours) might be related to the distance between the patients' residence (greater than 900 $\mathrm{km}$ ) and the nearest healthcare facility or may be due to the availability and quality of roads, topography, land cover, and means to arrive at the CEMETRON to receive specialized care. These data are in agreement with those reported in previous studies ${ }^{24}$. However, a study conducted in Costa Rica ${ }^{19}$ showed that $61 \%$ of the patients reached the hospital within 3 hours and $20 \%$ after more than 5 hours. These studies noted the same observation about the logistical issues, such as effective communication with ambulance facilities, the availability of ambulances, and problems with other forms of transportation in the communities, which also need to be considered ${ }^{19}$.

The average period that the patient stays in the hospital was 5 days. Statistical analysis showed a significant (p-value $<0.05$ ) difference in the median hospital stay between patients who underwent surgery and those who did not have surgery. 
TABLE 2: Descriptive analysis of snakebite cases registered in the present study, and the signs and symptoms by sex.

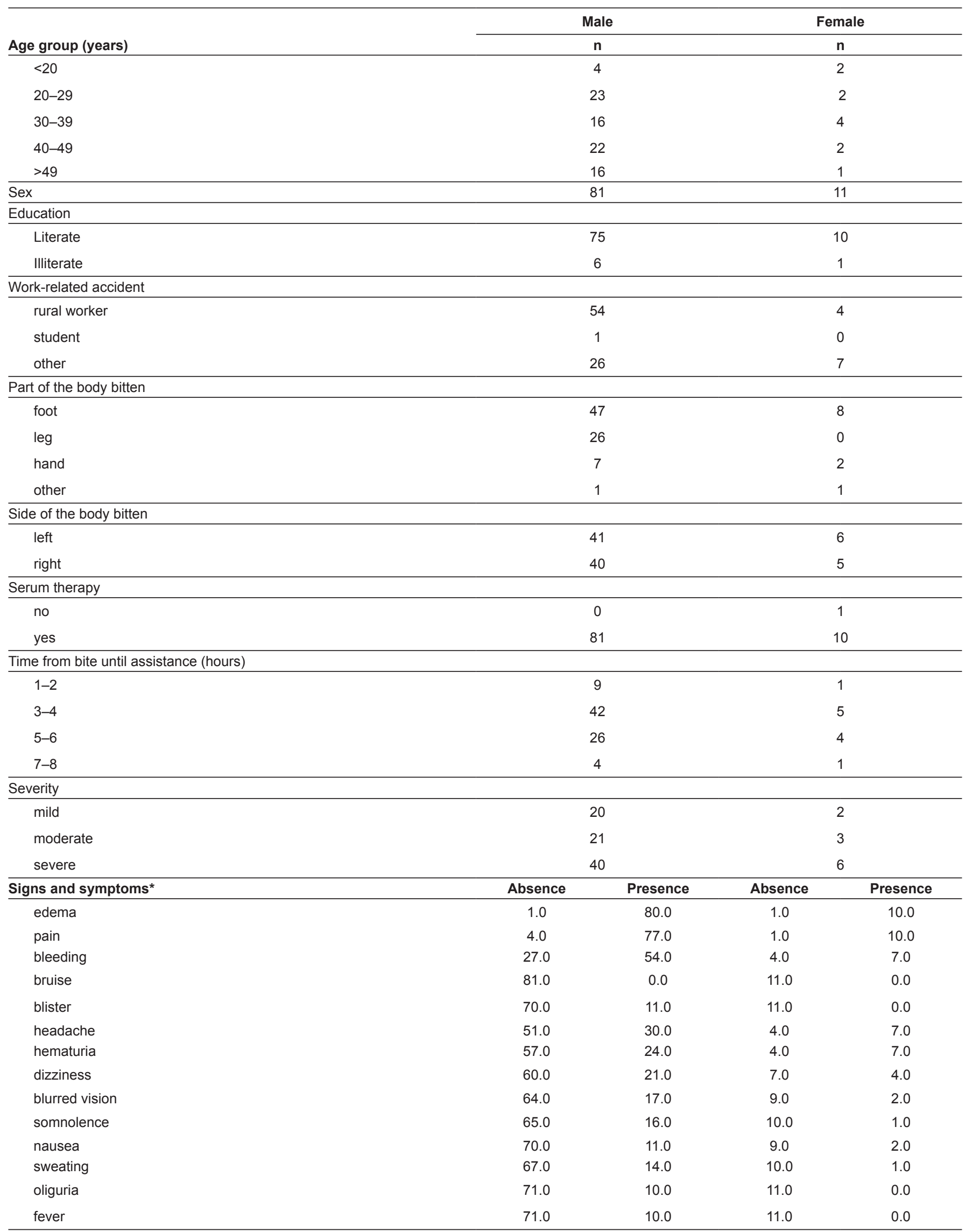

*Major clinical systemic symptoms found in snakebites. The results are expressed in percentages. 
TABLE 3: Accident classification.

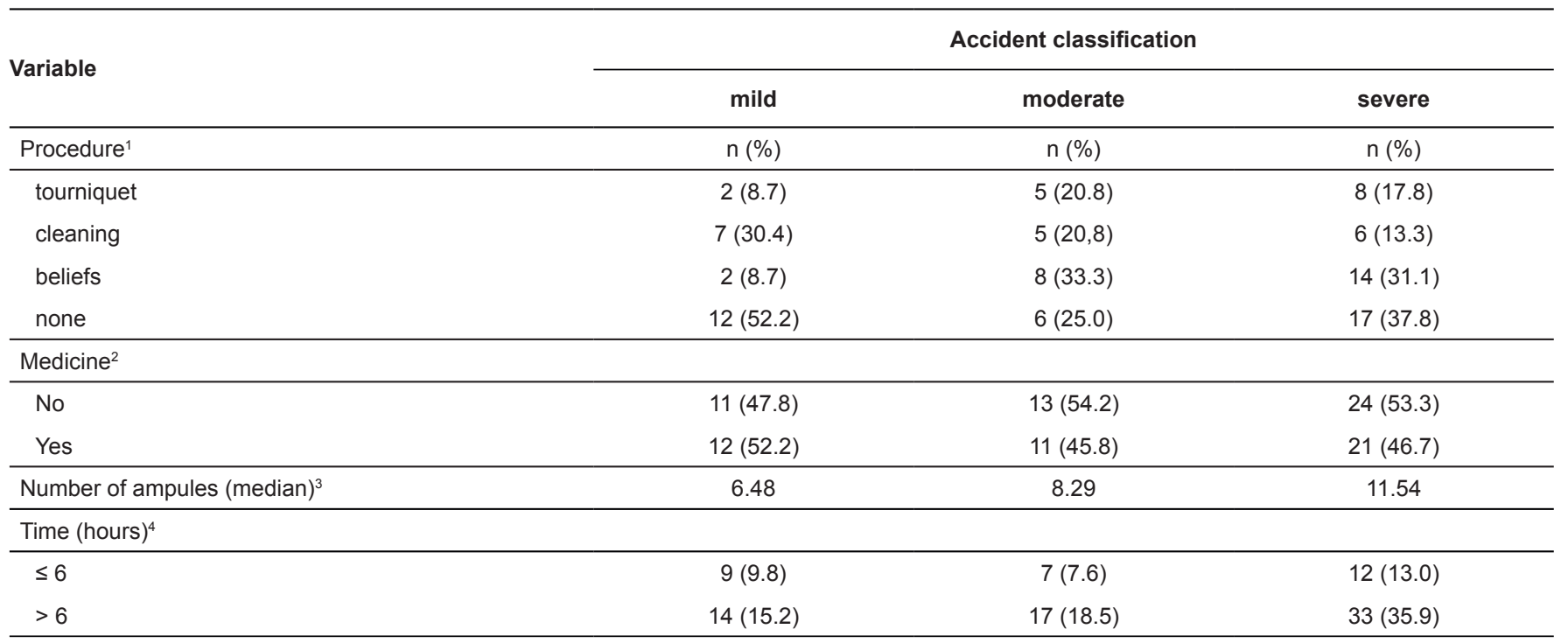

${ }^{1}$ Procedure used. Crossing made between procedures performed by patients after the bite and classification of accidents in severity (mild, moderate, and severe). This classification was performed after obtaining patients' clinical history and conducting a physical examination, as recommended by the MH. We used the chi-square test for the statistical analysis. ${ }^{2}$ Alternative medicine. Crossing conducted between accident classification (mild, moderate, and severe) and the use or non-use of alternative medicines by patients. For statistical analyses, we used the chi-square test. ${ }^{3}$ Median number of ampules used (without percentage). ${ }^{4}$ Time elapsed between the accident and the arrival to the hospital. Crossing conducted between time elapsed between the accident and the arrival to the hospital versus accident classification (mild, moderate, and severe). We used the chi-square test for the statistical analysis.

Moreover, the statistical analysis showed some significant differences ( $p$ value $<0.05$ ) between the median length of hospital stay and the classification of snakebites. Patients with severe snakebites had a median length of hospital stay of around 11 days; those with moderate snakebites, 3 days; and those with mild snakebites, 2 days.

Snakebite severity correlated with the elapsed time before arrival at the hospital ( $>6 \mathrm{~h})$. Approximately $48.9 \%$ of snakebite cases were classified as severe, but there was no association between the two previously mentioned variables (Table 3 ). In this study, 88 (95.7\%) cases could completely recover. However, the following after-effects were observed in $4(4.3 \%)$ patients: deformity of the lower limb, amputation, and loss of skin, subcutaneous tissue, and muscle. No deaths were reported. Bothropic systemic manifestations varied, with the involvement of multiple organs, which reflect the large number of general and specific clinical findings. These manifestations may present intestinal, hematologic, renal, cardiovascular, or nonspecific (sweating, myalgia, hypothermia, and hyperthermia) symptoms. In this study, hematuria $(31.5 \%)$, dizziness $(25 \%)$, oliguria $(8.7 \%)$, and fever $(7.6 \%)$ were the most commonly observed systemic changes.

Serum therapy was used in $92(100 \%)$ cases. The most commonly administered antivenom was antibothropic serum [83 $(90.2 \%)$ cases; $5 \mathrm{mg} / \mathrm{mL}$ of intravenous pentavalent antibothropic serum - a neutralizing titer], followed by antibothropic-laquetic serum [7 (7.6\%) cases; $5 \mathrm{mg} / \mathrm{mL}$ of intravenous pentavalent antibothropic-lachetic serum-a neutralizing titer] and antielapidic serum [2 (2.2\%) cases; $1.5 \mathrm{mg} / \mathrm{mL}$ of intravenous pentavalent antielapidic serum-a neutralizing titer].
Table 3 shows that the average number of antivenom ampules used varied according to severity, from 6.5 to 11.5 ampules [mild: 6.5 (1.95); moderate: 8.3 (2.53); and severe: 11.5 (2.58)]. Antibiotic therapy was conducted in 45 (48.9\%) patients; most (30 cases) of them had severe envenomations.

Considering that the average number of ampules used varied according to the severity of snakebites, it was observed that the average number of ampules used in moderate cases was based on the recommendations provided by the MH. However, such average numbers were respectively lower and higher than those recommended for mild and severe cases. This result demonstrates the lack of clinical and epidemiological knowledge for the real classification of snakebites and the inadequate administration dose/ampules of antivenom, which was also observed in a previous study ${ }^{6}$.

It is important to note that the antibothropic serum produced by the Butantan Institute, Ezequiel Dias Foundation, and Vital Brazil Institute was prepared by the hyperimmunization of horses with a pool of venoms from Bothrops alternatus, Bothrops jararaca, Bothrops jararacussu, Bothrops moojeni, and Bothrops neuwiedi $i^{28,29}$ without Bothrops atrox. This may explain, in most cases, why the antivenom does not effectively neutralize many toxins present in the venoms, especially those with low molecular weight and low antigenicity.

Furthermore, we found a prevalence of edema $(94.5 \%)$, pain (93.5\%), and bleeding (64.2\%) and less frequently, bruises, blisters, necrosis, and abscesses in patients with bothropic envenomation (Table 2). Similar data were found in previous studies ${ }^{20,21,26}$. Local changes were associated with the proteolytic action of venom from Bothrops snakes, which is inefficiently 
TABLE 4: Biochemical parameters pre- and post-antivenom therapy.

\begin{tabular}{|c|c|c|c|}
\hline Antivenom & Median & Q1 & Q3 \\
\hline \multicolumn{4}{|c|}{ Creatine kinase } \\
\hline post & 640.00 & 348.00 & 980.00 \\
\hline \multicolumn{4}{|c|}{ Alanine aminotransferase } \\
\hline post & 30.67 & 15.00 & 101.00 \\
\hline \multicolumn{4}{|c|}{ Aspartate aminotransferase } \\
\hline pre & 49.12 & 11.00 & 201.00 \\
\hline pre & 6.26 & 5.00 & 30.00 \\
\hline post & 6.59 & 5.00 & 16.00 \\
\hline \multicolumn{4}{|l|}{ Creatinine } \\
\hline pre & 0.94 & 0.42 & 2.90 \\
\hline post & 0.82 & 0.38 & 3.20 \\
\hline \multicolumn{4}{|l|}{ Urea } \\
\hline pre & 31.50 & 10.00 & 132.00 \\
\hline
\end{tabular}

Q1: First Quartile; Q3: Third Quartile.

neutralized by available antivenoms, even when administered immediately after the snakebite ${ }^{27}$.

To evaluate the clinical and laboratory profile of cases of envenomation, we conducted a study to analyze the systemic alterations induced by envenomation before and after serum therapy. Initially, patients' laboratory results showed a decrease in hematocrit levels after comparing the red blood cell and white blood cell (WBC) counts pre-serum (40.43\%) and post-serum (34.6\%). The same was observed with hemoglobin levels, but with less variation (pre-serum: $14.5 \%$ and post-serum: $12.3 \%$ ). All levels were compared, and no significant ( $p$-value $>0.05$ ) changes were observed.

Upon admission (pre-serum), patients had a mean leukocyte count of $16.800 / \mathrm{mm}^{3}$. After serum therapy, the values of WBC counts decreased, but were still above normal levels. The pre- and post-serum platelet count did not change significantly ( $p$-value $>0.05$ ), remaining within the normal range.

The occurrence of leukocytosis with neutrophilia in patients is related to the endocrine-metabolic response to trauma, where the inoculated venom induces neutrophils, due to the action of metalloproteinases and disintegrins, the protein components present in the venom of Bothrops atrox snakes (the main
Bothrops snake involved in the envenomations in the Amazon region), which has been shown in experimental studies ${ }^{11}$. Local and systemic effects identified in Bothrops envenomations are due to the proteolytic, hemorrhagic, and nephrotoxic effects of the venom ${ }^{20}$.

Surgical procedures were performed in $10.9 \%$ of patients. Fasciotomy was executed in nine cases (one case of a Lachesis snakebite and eight cases of Bothrops envenomations, all classified as severe and moderate snakebites, respectively). In addition to the usual treatment of envenoming and its complications, as recommended by the Brazilian $\mathrm{MH}$, tetanus prophylaxis is mandatory for all snakebite cases ${ }^{6}$. In this study, prophylaxis was performed in only 54 (58.7\%) cases.

In addition to tetanus prophylaxis, the Brazilian $\mathrm{MH}$ recommends that laboratory tests must be routinely performed for all snakebite $\operatorname{cases}^{30}$. Most of studies shows clinical and epidemiological data and did not include the results of laboratory tests. Among the abnormal laboratory results that are frequently observed in research studies is the $\mathrm{CT}^{31,32}$. The lack of studies that include patients' laboratory test results during hospitalization and after antivenom therapy makes it difficult to compare the findings in this work. 
With regard to CT, $33(35.9 \%)$ of the 92 patients who had incoagulable CT received pre-antivenom therapy, with complete CT normalization 48 hours after serum therapy (CT $<11$ minutes Technical Lee-White), and 26 (28.2\%) patients showed a normal CT (clottable). Finally, the remaining 33 patients were discharged from the hospital before 48 hours, making it impossible to determine their CT.

Although it is preconized by the Brazilian $\mathrm{MH}, \mathrm{CT}$ test was not performed 48 hours after antivenom in a group of 33 patients who were admitted in CEMETRON. These patients were discharged early, before 48 hours, due to the significant increase in the number of dengue cases in 2009, exceeding the capacity of beds in the center of reference. Milani and coauthors ${ }^{20}$ evaluated the $\mathrm{CT}$ of 2,990 patients with snakebites and noted a blood incoagulability rate of $46.7 \%$. These changes tend to baseline with the neutralization of venom (post-antivenom), which was also observed in the literature ${ }^{33-35}$.

Serum creatinine and urea are the most commonly used parameters for evaluating renal function in the clinical practice. Their normal values range from 0.4 to $1.2 \mathrm{mg} / \mathrm{dL}$ and 10 to $50 \mathrm{mg} /$ $\mathrm{dL}$, respectively. When these markers were analyzed before and after antivenom treatment, some changes in the creatinine levels were observed (pre-serum $=0.94$ and drops to 0.82 in post-serum). The same occurs for urea (pre-serum $=31.5$ and drops to 24.17 in post-serum).

Another evaluated marker was CK, an enzyme that is present in high levels in patients bitten by snakes. The median preserum CK level was $690 \mathrm{U} / \mathrm{L}$, while after 48 hours of antivenom treatment, the level was 640U/L (Table 4).

In our study, the pre- and post-serum analyses showed that there was a median decrease in ALT (Table 4) and AST (Table 4) levels. Snakebites can lead to liver changes with elevations in ALT levels. This change is described in crotalid envenomations ${ }^{2,3}$. There was an increase in ALT levels after antivenom therapy. Hence, further studies need to be conducted to elucidate these increased ALT levels and define possible causes for this increase (hepatotoxicity of Bothrops snake venom or complication of antivenom used).

In conclusion, a clear majority of snakebite cases reported in this study were apparently caused by Bothrops snakes, which have similar epidemiological and clinical characteristics as those found in other literature. This follow-up study may contribute to a better understanding of envenomation in the State of Rondônia and can be useful for identifying real conditions that increase snakebites in this region.

\section{Acknowledgments}

The authors express their gratitude to Financiadora de Estudos e Projetos (FINEP), Coordenação de Aperfeiçoamento de Pessoal de Nivel Superior (CAPES)-Projeto NanoBiotec, Rede de Biodiversidade e Biotecnologia da Amazônia Legal - Conselho Nacional de Desenvolvimento Científico e Tecnológico - Ministério da Ciência e Tecnologia (BIONORTE/CNPq/MCT), and Secretaria de Estado do Planejamento (CNPq-SEPLAN-RO). We would like to acknowledge Msc. Mahmoud Baydoun for reviewing the English of this article. We also thank Ana Lorena Vasconcelos, Bruna Cândido, Nídia Abreu, and Renata Catiari, the Scientific Initiation students from UNIR.

\section{Conflict of interests}

The authors declare that there is no conflict of interest.

\section{Financial support}

This study was supported by grants (473999/2008-0 and 482562/2010-2) from Conselho Nacional de Desenvolvimento Científico e Tecnológico (CNPq). Juliana Pavan Zuliani was a recipient of productivity grants 303974/2008-7 and 301809/2011-9 from CNPq.

\section{REFERENCES}

1. Chippaux JP. Incidence and mortality due to snakebite in the Americas. PLoS Negl Trop Dis. 2017;11(6):e0005662.

2. Chippaux JP. Snakebite envenomation turns again into a neglected tropical disease! J Venom Anim Toxins Incl Trop Dis. 2017;23(1):38.

3. Kasturiratne A, Wickremasinghe AR, de Silva N, Gunawardena NK, Pathmeswaran A, Premaratna R, et al. The global burden of snakebite : a literature analysis and modelling based on regional estimates of envenoming and deaths. PLoS Med. 2008;5(11):e218.

4. Harrison RA, Hargreaves A, Wagstaff SC, Faragher B, Lalloo DG. Snake envenoming: a disease of poverty. PLoS Negl Trop Dis. 2009;3(12):e569.

5. World Health Organization (WHO). Snakebite envenoming. Neglected tropical diseases. Genève: WHO; 2018. Available from: http://www.who.int/snakebites/en/

6. Fundação Nacional de Saúde (FUNASA). Manual de Diagnóstico e Tratamento de Acidentes por Animais Peçonhentos. Brasília: Ministério da Saúde; 2001. 112p. http://bvsms.saude.gov.br/bvs/ publicacoes/funasa/manu_peconhentos.pdf

7. Gutiérrez JM. Envenenamientos por mordeduras de serpientes en América Latina y el Caribe: una visión integral de carácter regional. Bol Malariol y Salud Ambient. 2011;51(1):1-16.

8. Gutiérrez JM. Reducing the impact of snakebite envenoming in Latin America and the Caribbean: achievements and challenges ahead. Trans R Soc Trop Med Hyg. 2014;108(9):530-7.

9. Oliveira RC, Wen FH, Sifuentes D. Epidemiologia dos acidentes por animais peçonhentos. In: Cardoso JLC, França FOS, Fan HW, Málaque CMS, Haddad VJ, editors. Animais Peçonhentos do Brasil: Biologia, Clínica e Terapêutica dos Acidentes. $2^{\text {nd }}$ edition. São Paulo: Sarvier; 2009. p. 6-21.

10. Gutiérrez JM, Williams D, Fan HW, Warrell DA. Snakebite envenoming from a global perspective: towards an integrated approach. Toxicon. 2010;56(7):1223-35.

11. Gutiérrez JM. Snakebite Envenoming: A Public Health Perspective. In: Public Health Perspective - Methodology, Environmental and Systems Issues; 2012. p. 131-62. doi: 10.5772/36076.

12. Melgarejo AR. Serpentes Peçonhentas do Brasil. In: Cardoso JLC, França FOS, Fan HW, Málaque CMS, Haddad, VJ, editors. Animais Peçonhentos do Brasil: Biologia, Clínica e Terapêutica dos Acidentes. $2^{\text {nd }}$ edition. São Paulo: Sarvier; 2009. p. 42-70.

13. Bérnils RS, Costa HC. Répteis brasileiros: lista de espécie. São Paulo: Sociedade Brasileira de Herpetologia; 2012.

14. Bernarde P, Albuquerque S, Barros TO, Turci LCB. Serpentes do Estado de Rondônia, Brasil. Biota Neotrop. 2012;12(3):154-82.

15. Pardal P, Bezerra IS, Rodrigues LS, Pardal JSO, Farias PHS. Acidente por Surucucu (Lachesis muta muta) em Belém-Pará: Relato de caso. Rev Para Med. 2007;21(1):37-42. 
16. Instituto Brasileiro de Geografia e Estatística (IBGE). IBGE Cidades. Brasília: IBGE; 2014. Disponível em: http://www.cidades. ibge.gov.br/xtras/home.php

17. Fearnside PM. Impacts of Brazil's Madeira River Dams: Unlearned lessons for hydroelectric development in Amazonia. Environ Sci Policy. 2014;38:164-72.

18. da Silva CJ, Jorge MT, Ribeiro LA. Epidemiology of snakebite in a central region of Brazil. Toxicon. 2003;41(2):251-5.

19. Hansson E, Sasa M, Mattisson K, Robles A, Gutiérrez JM. Using geographical information systems to identify populations in need of improved accessibility to antivenom treatment for snakebite envenoming in Costa Rica. PLoS Negl Trop Dis. 2013;7(1):e2009.

20. Milani Jr R, Jorge MT, de Campos FP, Martins FP, Bousso A, Cardoso JL, et al. Snake bites by the jararacucu (Bothrops jararacussu): clinicopathological studies of 29 proven cases in São Paulo State, Brazil. QJ Med. 1997;90(5):323-34.

21. Bochner R, Struchiner CJ. Epidemiologia dos acidentes ofídicos nos últimos 100 anos no Brasil: uma revisão. Cad Saúde Pública. 2003;19(1):7-16.

22. Mise YF, Lira-da-Silva RM, Carvalho FM. Envenenamento por serpentes do gênero Bothrops no Estado da Bahia: aspectos epidemiológicos e clínicos. Rev Soc Bras Med Trop. 2007;40(5):56973.

23. Saravia P, Rojas E, Arce V, Guevara C, López JC, Chaves E, et al. Geographic and ontogenic variability in the venom of the neotropical rattlesnake Crotalus durissus: pathophysiological and therapeutic implications. Rev Biol Trop. 2002;50(1):337-46.

24. Moreno E, Queiroz-Andrade M, Lira-da-Silva RM, Tavares-Neto J. Características clínicoepidemiológicas dos acidentes ofídicos em Rio Branco. Acre. Rev Soc Bras Med Trop. 2005;38(1):15-21.

25. Warrell DA. Snake bite. Lancet. 2010;375(9708):77-88.

26. Borges CC, Sadahiro M, Santos MC. Aspectos epidemiológicos e clínicos dos acidentes ofídicos ocorridos nos municípios do Estado do Amazonas. Rev Soc Bras Med Trop. 1999;32(6):637-46.
27. World Health Organization (WHO). Guidelines for the Production, Control and Regulation of Snake Antivenom Immunoglobulins; Genève: WHO; 2010. Available from: http://www.who.int/ bloodproducts/snake_antivenoms/snakeantivenomguide/en/

28. O'Leary MA, Isbister GK, Schneider JJ, Brown SGA, Currie BJ. Enzyme immunoassays in brown snake (Pseudonaja spp.) envenoming: detecting venom, antivenom and venom-antivenom complexes. Toxicon. 2006;48(1):4-11.

29. Theakston RD, Reid HA. Development of simple standard assay procedures for the characterization of snake venom. Bull World Health Organ. 1983;61(6):949-56.

30. Rojas CA, Almeida-Santos SM, Gonçalves MR. Epidemiologia dos acidentes ofídicos na região noroeste do estado de São Paulo, Brasil. Rev Bras Saúde Prod An. 2007;8(3):193-204.

31. de Souza CAT, Kayano AM, Setúbal SS, Pontes AS, Furtado JL, Kwasniewski FH, et al. Local and systemic biochemical alterations induced by Bothrops atrox snake venom in mice. J Venom Res. 2012;3:28-34.

32. Escocard RC, Kanashiro MM, Petretski JH, Azevedo-Silva J, Queiroz de Carvalho EC, Dias da Silva W, et al. Neutrophils regulate the expression of cytokines, chemokines and nitric oxide synthase/nitric oxide in mice injected with Bothrops atrox venom. Immunobiology. 2006;211(1-2):37-46.

33. de Andrade Moura L, Marqui de Almeida AC, Domingos TFS, Ortiz-Ramirez F, Cavalcanti DN, Teixeira VL, et al. Antiplatelet and anticoagulant effects of diterpenes isolated from the marine alga, Dictyota menstrualis. Mar Drugs. 2014;12(5):2471-84.

34. Sano-Martins IS, Santoro ML. Distúrbios hemostáticos em envenenamentos por animais peçonhentos do Brasil. In: Cardoso JLC, França FOS, Fan HW, Málaque CMS, Haddad VJ, editors. Animais Peçonhentos do Brasil: Biologia, Clínica e Terapêutica dos Acidentes. $2^{\text {nd }}$ edition. São Paulo: Sarvier; 2009. p. 289-309.

35. França FOS, Málaque CMS. Acidente botrópico. In: Cardoso JLC, França FOS, Fan HW, Málaque CMS, Haddad VJ, editors. Animais Peçonhentos do Brasil: Biologia, Clínica e Terapêutica dos Acidentes. $2^{\text {nd }}$ edition. São Paulo: Sarvier; 2009. p. 81-95. 